\title{
Sperm quality assessments for endangered razorback suckers Xyrauchen texanus
}

\author{
Jill A Jenkins, Bruce E Eilts ${ }^{1}$, Amy M Guitreau ${ }^{2}$, Chester R Figiel ${ }^{3}$, Rassa O Draugelis-Dale \\ and Terrence R Tiersch ${ }^{2}$
}

US Geological Survey, National Wetlands Research Center, 700 Cajundome Boulevard, Lafayette, Louisiana 70506, USA, ${ }^{1}$ Department of Veterinary Clinical Sciences, School of Veterinary Medicine, Louisiana State University, Baton Rouge, Louisiana 70803, USA, ${ }^{2}$ Aquaculture Research Station, Louisiana State University Agricultural Center, Louisiana Agricultural Experiment Station, Baton Rouge, Louisiana 70803, USA and ${ }^{3}$ US Fish and Wildlife Service, Willow Beach National Fish Hatchery, 25804 North Willow Beach Road, Willow Beach, Arizona 86445, USA

Correspondence should be addressed to J A Jenkins; Email: jenkinsj@usgs.gov

A M Guitreau is now at A Woman's Center for Reproductive Medicine, 9000 Airline Hwy, Baton Rouge, Louisiana 70815, USA C R Figiel is now at US Fish and Wildlife Service, Warm Springs Fish Technology Center, 5308 Spring Street, Warm Springs, Georgia 31830, USA

\begin{abstract}
Flow cytometry (FCM) and computer-assisted sperm motion analysis (CASA) methods were developed and validated for use with endangered razorback suckers Xyrauchen texanus collected $(n=64)$ during the 2006 spawning season. Sperm motility could be activated within osmolality ranges noted during milt collections (here $167-343 \mathrm{mOsm} / \mathrm{kg}$ ). We hypothesized that sperm quality of milt collected into isoosmotic (302 $\mathrm{mOsm} / \mathrm{kg})$ or hyperosmotic $(500 \mathrm{mOsm} / \mathrm{kg})$ Hanks' balanced salt solution would not differ. Pre-freeze viabilities were similar between osmolalities (79\% \pm 6 (S.E.M.) and $76 \% \pm 7$ ); however, post-thaw values were greater in hyperosmotic buffer ( $27 \% \pm 3$ and $12 \% \pm 2 ; P=0.0065)$, as was mitochondrial membrane potential $(33 \% \pm 4$ and $13 \% \pm 2 ; P=0.0048)$. Visual estimates of pre-freeze motility correlated with total $(r=0.7589$; range $23-82 \%)$ and progressive motility $(r=0.7449)$ by CASA and were associated with greater viability $(r=0.5985 ; P<0.0001)$. Count $(F C M)$ was negatively correlated with post-thaw viability $(r=-0.83 ; P=0.0116)$ and mitochondrial function $(r=-0.91 ; P=0.0016)$. By FCM-based assessments of DNA integrity, whereby increased fluorochrome binding indicated more fragmentation, higher levels were negatively correlated with count $(r=-0.77 ; P<0.0001)$ and pre-freeze viabilities $(r=-0.66 ; P=0.0004)$. Fragmentation was higher in isotonic buffer $(P=0.0234)$. To increase reproductive capacity of natural populations, the strategy and protocols developed can serve as a template for use with other imperiled fish species, biomonitoring, and genome banking.

Reproduction (2011) 141 55-65
\end{abstract}

\section{Introduction}

A primary focus of the propagation program for the Federally listed endangered razorback suckers Xyrauchen texanus (US Fish \& Wildlife Service 1991) has been to slow the loss of biodiversity through improved genetic management by augmenting populations using either wild-born larvae from naturally spawning adults or hatchery fish (progeny produced by artificial cultivation with broodstock; US Fish \& Wildlife Service 2002). This riverine catostomid in the order Cypriniformes was formerly abundant throughout the entire lower Colorado River drainage (Minckley et al. 1991), but the current range for the residual wild populations is primarily limited to Lake Mead, Lake Mohave (Mueller et al. 2000), and the middle Green River drainage (Modde et al. 1996, Cooke et al. 2005). Although the low levels of recruitment (replacement with younger individuals) have been directly linked to competition with, and predation by, non-native fish introduced for sportfishing (Minckley et al. 1991), the reduced availability of floodplain habitat (Modde et al. 1996) and the continued declines of flows into the Colorado River (Barnett \& Pierce 2008) will likely exacerbate the predicted losses of remaining sustainable populations of razorback suckers. Selenium (Waddell \& May 1995) and sublethal concentrations of contaminants (US Fish \& Wildlife Service 2002) have also been implicated in population declines.

Strategies using assisted-reproductive techniques (ART) with endangered animals require methods targeted to species-specific reproductive biology (Comizzoli et al. 2000), and ART is often the final effort at maintaining genetic diversity in declining wildlife 
populations (Bawa et al. 1997). Facilitating the transfer of gametes from wild fish populations for use in hatcheries necessitates research into milt collection, storage methods, extender types, as well as into sperm cell quality. Thus, far, advances in ART with razorback sucker milt are consequences of integrating field studies with annual samplings (Carmichael et al. 1996) that have lead to sperm cryopreservation under hatchery conditions. In those studies, sperm motility estimates and fertilization trials comprised the evaluations of sperm cell quality (Tiersch et al. 1998). However, combinations of assays are necessary for selecting germplasm for immediate use and for building functional genetic resource banks for endangered species (Bainbridge \& Jabbour 1998). Progress on sperm cryopreservation with other endangered fish species includes work with Formosan landlocked salmon Oncorhynchus masou formosanus (Gwo et al. 1999), pallid sturgeon Scaphirhynchus albus (Wayman 2003), and Tokyo bitterling Tanakia tanago (Ohta et al. 2001).

For spermatozoal competence, cell structures must be intact and functional, yet cryopreservation can alter cell composition and physiology to compromise fertilizing potential (Ohta et al. 2001). Steps involved in sperm processing and cryopreservation can damage organelles, membranes, and DNA (Drokin et al. 1998, Cabrita et al. 2001), and can reduce motility (Soler et al. 2005, Silva \& Gadella 2006). Various tests have been used for predicting fertilization (Jenkins 2000), for successful freezing (Hernández et al. 2006), and for measuring cell damage induced by cryopreservation (cryoinjury; Terner 1986, Linhart et al. 2005, Soler et al. 2005). In aquatic species, a motility estimate made visually is the most frequent sperm quality assessment (Terner 1986), but as with mammals, it is not always correlated with fertilization (Ericsson et al. 1993) or with other sperm quality indicators (Soler et al. 2005). Computer-assisted sperm motion analysis (CASA), primarily used with domestic animals, humans, and some aquatic species (Rurangwa et al. 2004), offers rapid and objective quantification of sperm motility parameters. Because razorback sucker spermatozoa are motile for $<1 \mathrm{~min}$ following activation by hypoosmotic pressure (Tiersch et al. 1997), CASA would improve accuracy of motility assessments with this species.

Prognostic evaluators recognized by the World Health Organization (WHO 1987) typically applied to human and domestic animal semen include sperm motility, sperm morphology, and sperm counts, which is a fundamentally important predictor of male fertility (Haubruge et al. 2000). The spermatocrit is often applied with aquatic species, and densities have been related to fertilization rates in Atlantic salmon Salmo salar (Aas et al. 1991). However, as with mammals, no single sperm count method is typical across aquatic species studies.

Functional analyses, including evaluations of sperm membrane integrity (viability), mitochondrial membrane potential (mitochondrial function), acrosomes, and chromatin are complementary to conventional andrology endpoints (Soler et al. 2005). For endangered aquatic species and their surrogates (Wayman 2003, Jenkins \& Goodbred 2005, Jenkins \& Draugelis-Dale 2006, Goodbred et al. 2007, Horváth et al. 2008), and for fish and shellfish (Segovia et al. 2000, Cabrita et al. 2001, Paniagua-Chavez et al. 2006, Tiersch et al. 2007, Horváth et al. 2008), viability and mitochondrial function assessments have proven useful. Mitochondrial respiration is responsible for ATP synthesis and sperm motility (Johnson et al. 1980), whereby mitochondrial membrane electrical potential has been correlated with mammalian spermatozoal normal morphology, concentration, and motility (Ericsson et al. 1993, Marchetti et al. 2002) and with motilities in Nile tilapia Oreochromis niloticus (Segovia et al. 2000) and in eastern oyster Crassostrea virginica (Paniagua-Chavez et al. 2006). Although mitochondrial membrane potential was the most sensitive test in determining human sperm quality (Marchetti et al. 2002) and likely provides insight with paddlefish Polyodon spathula (Horváth et al. 2008), sperm DNA integrity has been expected to yield superior diagnostic and prognostic information on fertility potential (Agarwal \& Said 2003).

The integrity of paternal DNA is essential for the accurate transmission of genetic information (Ahmadi \& $\mathrm{Ng}$ 1999, Ausió et al. 2009). Although defects in sperm chromatin have been negatively correlated with human fertility potential (Spanò et al. 2000) and golden hamster Mesocricetus auratus and human embryo development (Ahmadi \& Ng 1999), the fertilization process may not be inhibited (Ahmadi \& Ng 1999, Evenson et al. 2007). During milt storage and handling, degraded cellular and nuclear proteins can induce autolysis, DNA strand breaks, and decondensation, whereby chromatin becomes more vulnerable to nucleases and polymerases (Donnelly et al. 2001), and stainability is enhanced (Alanen et al. 1989). Milt contaminated with urine, as observed with razorback suckers (Tiersch et al. 2007) and marine fish species (Suquet et al. 2000), creates unfavorable osmotic conditions allowing sperm activation and consequent cell degradation. Cryopreservation-induced DNA damage has been shown in spermatozoa from sea bass Dicentrarchus labrax (Zilli et al. 2003), rainbow trout Oncorhynchus mykiss (Labbe et al. 2001), and infertile men (Donnelly et al. 2001).

Investigations for measuring sperm DNA damage have looked at DNA condensation, breaks and nicks, and nuclear fragmentation (Silva \& Gadella 2006). Techniques have included single-cell gel electrophoresis or 'comet assay' (Singh et al. 1989), sperm chromatin structure assay (Evenson et al. 1999, Peris et al. 2004), chromatin dispersion (López-Fernández et al. 2009), and TUNEL (Sailer et al. 1995), yet protocols are not standardized among laboratories (Tice et al. 2000). 
By flow cytometry (FCM) methodology, DNA strand breaks allow for enhanced binding of fluorescent dyes to DNA (Alanen et al. 1989), with greater dispersion of DNA indicated by increased coefficient of variation (CV; Shapiro 1995) or widening of the main histogram peak. After treatment with a variety of mutagens, nuclear peak widening has been observed (Dallas \& Evans 1990), as with the 1C (haploid) peak of rat testicular cells (Bickham et al. 1992). By FCM, nuclear subpopulations with increased chromatin staining by fluorochromes may also be discernable by size (Zbieranowski et al. 1993). Advantages of FCM methods (Agarwal \& Said 2003) are that sample sizes are typically at least ten times larger than those for comet assay (Potter et al. 2002), interpretation of results is less subjective, and data can be collected and analyzed within a few minutes (Shapiro 1995).

The necessity of non-invasive sampling procedures with the endangered razorback suckers and the typical long-distance sample shipment to laboratories for cell quality analyses and potential genome banking are dependent on improved protocols for milt handling and cell quality analyses (Tiersch et al. 2004). Objective assessment methods with FCM and CASA, nevertheless, require standardization and optimization per species to obtain useful results (Verstegen et al. 2002). This study was undertaken to develop and apply sperm quality estimators relevant for evaluating razorback sucker milt, addressing an overall hypothesis that sperm quality would be similar from milt collected into buffer extenders of either high or low osmolality. Specific objectives included the development and validation of impartial sperm quality analyses based on CASA for sperm motility and on FCM for sperm count, viability, mitochondrial function, and DNA integrity.

\section{Results}

\section{Milt handling and morphology of spermatozoa}

Individual males ranged from 1.3 to $2.2 \mathrm{~kg}$, from 485 to $630 \mathrm{~mm}$, and between 2 and $17 \mathrm{ml}$ of milt were collected. Osmolalities of undiluted milt samples ranged from 167 to $343 \mathrm{mOsm} / \mathrm{kg}$, and spermatocrits ranged from 1 to $24.5 \%$. The primary abnormality observed was macrocephalus (Fig. 1). The percentage of abnormal cells that occurred in the low-osmolality buffer $(5.4 \% \pm 2.0)$ exceeded those in the high-osmolality buffer $(1.9 \%$ $\pm 0.5 \%)$, but the difference was not significant $(P=0.0927)$. The percentage of the morphological abnormalities ranged from 1.2 to $15.8 \%$ and from 0.6 to $4.4 \%$ for low and high osmolalities respectively.

\section{Motility}

Visual estimates of pre-freeze sperm motility were correlated with total motility $(r=0.7589)$ and progressive motility $(r=0.7449)$ measured by CASA $(n=13)$.
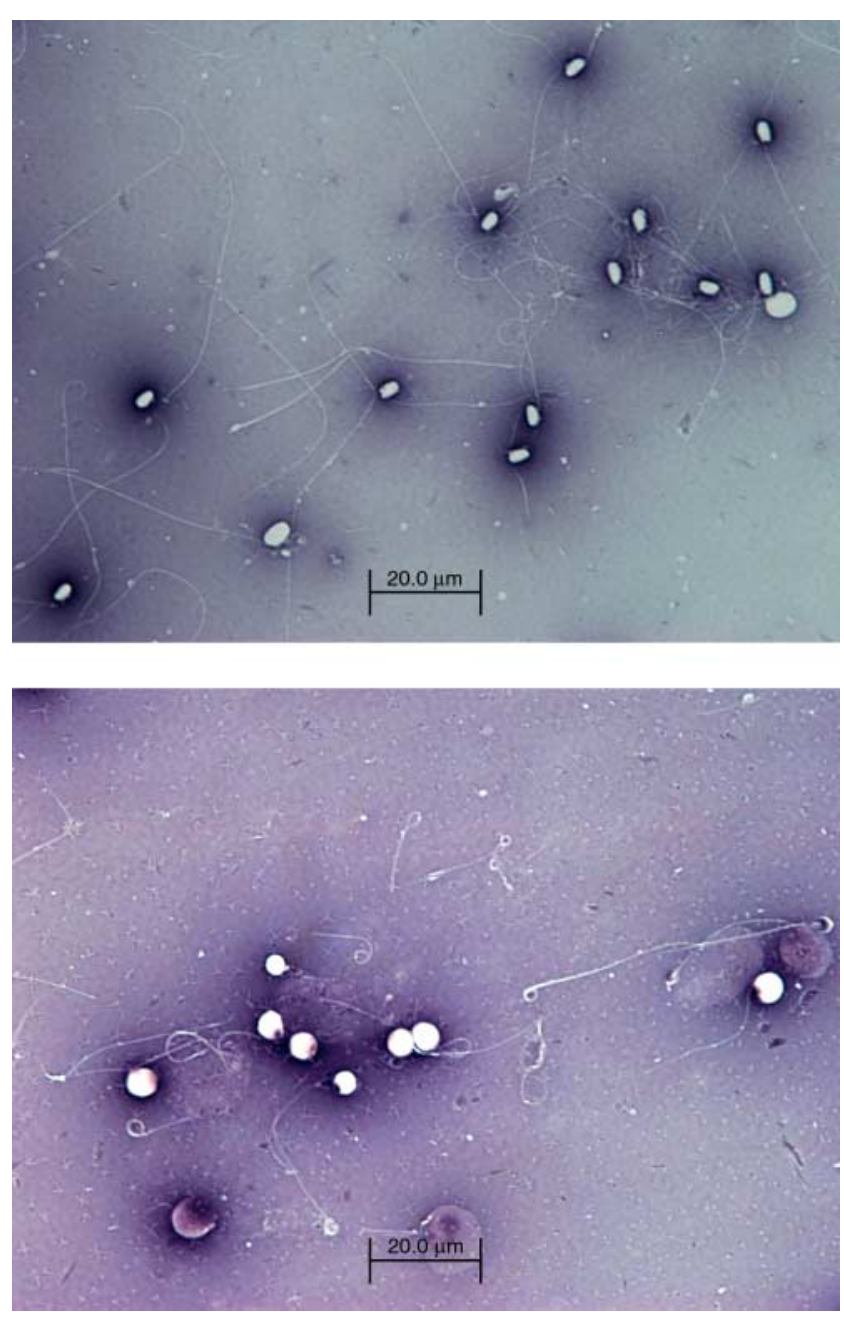

Figure 1 Eosin-nigrosin staining of razorback sucker spermatozoa imaged using light microscopy at $1000 \times(n=15)$. Milt was stored for $24 \mathrm{~h}$ in $302 \mathrm{mOsm} / \mathrm{kg}$ Hanks' balanced salt solution. The primary abnormality noted was macrocephalus, predominant in the lower image.

Total motility by CASA (range 23-82\%) had a slight positive linear association with viability $(r=0.5234$; $P=0.0985 ; n=11)$ and a negative association with DNA fragmentation $(r=-0.5152 ; P=0.0865 ; n=12)$. Higher visual motility estimates were associated with greater viability $(r=0.5985 ; P<0.0001 ; n=26)$. Sperm motility measured by CASA exhibited more straight $(r=0.636 ; y=0.146 x+4.976)$ than curvilinear $(r=0.259 ; y=0.088 x+15.833)$ motion. In the shortterm cold storage study (Fig. 2), no significant differences in motility were observed among the four buffers, but motilities in undiluted milt were significantly lower than those in milt stored in the four buffers $(P<0.0001)$. Over time, the motilities at time $0 \mathrm{~h}$ were significantly higher than those measured at $12 \mathrm{~h}$, and these were higher than values at both 24 and $33 \mathrm{~h}(P<0.0001)$. There was no significant interaction between buffers and time. 


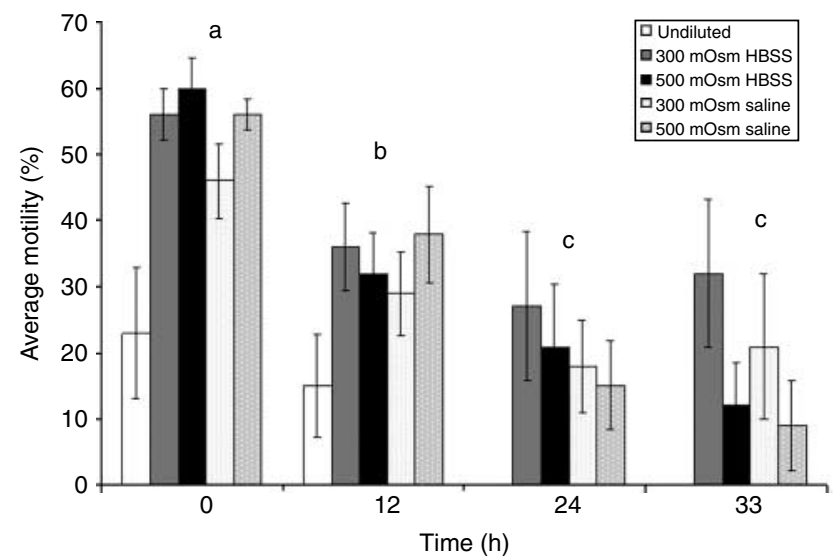

Figure 2 Estimates of motility made visually using razorback sucker milt collected into calcium-free Hanks' balanced salt solution (HBSS) or saline at either 302 or $500 \mathrm{mOsm} / \mathrm{kg}$ ( $n=10$ milt samples from the same individuals per time period and treatment). No significant differences were observed in motility among the four buffers tested, but motilities at time $0 \mathrm{~h}$ were significantly higher than those measured at $12 \mathrm{~h}$, and these were higher than values at 24 and $33 \mathrm{~h}(P<0.0001)$. The motility values of the undiluted samples were significantly lower at each time period than those stored in buffers $(P<0.0001)$.

\section{Viability and mitochondrial membrane potential}

To validate assays for viability and mitochondrial membrane potential, comparisons were made between values of predetermined live and dead sperm cell ratios (predicted) and actual values measured by FCM. Regression curves were generated using duplicate samples from each of three individuals. Equations for viability were $y=24.873 x-21.172\left(R^{2}=0.9857\right.$; fish \#1), $y=27.332 x-30.581 \quad\left(R^{2}=0.9505\right.$; fish \#2), and $y=23.955 x-11.786\left(R^{2}=0.9304\right.$; fish \#3). The equations for membrane potential were $y=25.233 x-$ $20.802 \quad\left(R^{2}=0.9708 ;\right.$ fish \#1), $y=27.408 x-42.713$ $\left(R^{2}=0.8539 ;\right.$ fish \#2), and $y=23.513 x-17.025$ $\left(R^{2}=0.9714\right.$; fish \#3). All these equations showed good fit between the predicted and actual values measured by FCM.

Ranges and averages of pre-freeze sperm viabilities were similar between the high- and low-osmolality buffer extenders used for milt collection (Table 1); however, post-thaw viability in the high-osmolality buffer was significantly greater $(P=0.0065)$. Post-thaw mitochondrial membrane potential from cells collected in the high-osmolality buffer was also significantly higher $(P=0.0048)$. The difference between pre-freeze and post-thaw viability values were greater for the lowosmolality buffer than for the high-osmolality buffer $(P=0.0089)$.

\section{Sperm counts}

Sperm counts measured by hemocytometer and flow cytometer were correlated $\left(y=1.2188 x+1 \times 10^{8}\right.$; $\left.R^{2}=0.8464\right)$. The sperm count measured by FCM ranged from $1.7 \times 10^{6}$ to $7.8 \times 10^{9}$ cells $/ \mathrm{ml}$. Spermatocrits were correlated with sperm counts measured by FCM $\left(y=16.632-2 \times 10^{-9} x ; R^{2}=0.3639\right)$ and by hemocytometer $\left(y=7.1104+5 \times 10^{-9} x ; R^{2}=0.4802\right)$. Sperm cell count (by FCM) was negatively correlated with postthaw viability $(r=-0.83 ; P=0.0116)$ and mitochondrial function $(r=-0.91 ; P=0.0016)$.

\section{DNA integrity}

Demonstrable DNA fragmentation was shown with razorback sucker spermatozoa exposed to hydrogen peroxide with nuclei outside the main population (NOMP) increasing from 1.55 to $12.24 \%$ using $0-100 \%$ hydrogen peroxide. The regression was significant $(P=0.0004)$ with $r=0.8572$ using a no-intercept model. The exposed control (common carp Cyprinus carpio) spermatozoa stained for DNA integrity immediately and following fixation showed increased CV with hydrogen peroxide concentration, with both regression models being no-intercept. For nuclei that were immediately stained, $r=0.8446(P=0.0344)$, and for fixed nuclei, $r=0.9573$ ( $P=0.0105)$. For NOMP, the regression models using fixed and live cells were no-intercept, with $r=0.9154(P=0.0291)$ and $r=0.8609(P=0.0277)$ respectively. The $C V$ of the shipped razorback sucker samples were positively correlated with NOMP $(r=0.8121 ; P<0.0001)$ by a linear with no-intercept

Table 1 Percentage viability and mitochondrial function (mean \pm s.E.M.) of razorback sucker spermatozoa prior to and following cryopreservation of milt collected into buffers* at 302 and $500 \mathrm{mOsm} / \mathrm{kg}$.

\begin{tabular}{|c|c|c|c|c|}
\hline & \multicolumn{2}{|c|}{ Pre-freeze } & \multicolumn{2}{|c|}{ Post-thaw } \\
\hline & $302 \mathrm{mOsm} / \mathrm{kg}$ & $500 \mathrm{mOsm} / \mathrm{kg}$ & $302 \mathrm{mOsm} / \mathrm{kg}$ & $500 \mathrm{mOsm} / \mathrm{kg}$ \\
\hline Viability $(\%)$ & $79.0(6.3)^{\mathrm{a}}$ & $76.1(7.1)^{\mathrm{a}}$ & $12.1(1.9)^{\mathrm{a}}$ & $27.0(2.6)^{b}$ \\
\hline Range $(\%)$ & $20.3-99.2$ & $21.4-98.6$ & $3.7-16.2$ & $18.0-37.7$ \\
\hline Sample size & 14 & 11 & 6 & 6 \\
\hline Mitochondrial function (\%) & $94.3(4.5)^{\mathrm{a}}$ & $33.9(0.0)^{\mathrm{a},+}$ & $13.0(2.0)^{\mathrm{a}}$ & $32.7(4.0)^{\mathrm{b}}$ \\
\hline Range & 80.9-98.9 & $32.1-37.7$ & $4.3-17.2$ & $23.5-46.3$ \\
\hline Sample size & 4 & 2 & 6 & 6 \\
\hline
\end{tabular}

*Hanks' balanced salt solution, calcium free. ${ }^{a, b}$ Different letters along rows within either the pre-freeze or post-thaw categories indicate significant statistical differences. ${ }^{\dagger}$ Because of the small sample size resulting from technical difficulties, statistics regarding this pre-freeze value are not discussed in the text. 
model. No significant difference was found between CV and NOMP analysis methods for assessing DNA fragmentation.

In razorback sucker samples, no differences among individual fish $(n=30)$ were observed in the percentage of cells with fragmented DNA, but there were significantly higher percentages from the low-osmolality buffer $(P=0.0234 ; n=30)$. The percentage of cells with fragmented DNA was negatively correlated with sperm cell count (by FCM; $r=-0.77 ; P<0.0001$ ) and with prefreeze viabilities $(r=-0.66 ; P=0.0004)$. When samples with over $10 \%$ fragmented nuclei were removed from statistical analysis, a strong negative correlation was also observed with spermatocrit $(r=-0.96 ; P=0.0006)$.

\section{Discussion}

Non-game fish, such as the catostomids, are not considered of direct economic or recreational benefit to humans and generally are not the subject of conservation efforts until they are imperiled (Cooke et al. 2005). One focal point for recovery of the endangered razorback suckers is to identify and maintain genetic diversity (US Fish \& Wildlife Service 2002). Owing to their endangered status, non-destructive and non-invasive techniques are crucial. Therefore, this study was designed to verify preferable conditions for milt handling in the field that would support meaningful gamete quality measurements in the laboratory and to validate a panel of sperm cell biomarkers for use with hatchery broodfish or wild-caught fish for immediate milt use in ART or in environmental assessments, as well as for evaluations following long-term storage by cryopreservation.

Limited sample sizes are inherent in studies with endangered animals. The technically sound methods and practical approach developed in this study with razorback suckers (Fig. 3) could be applied for use with other species offering similar challenges. Generally, ART for endangered mammalian species have been adapted from technologies developed in domestic species, and as with this study, methods need to be tailored to accommodate work under field conditions (Comizzoli et al. 2000). The results of this study support the collection of razorback sucker milt directly into a hyperosmotic extender to counteract potential damage caused by unavoidable and variable urine contamination.

Osmolality is lowered when urine is inadvertently collected along with palpated milt. With the threshold activation value at $264 \mathrm{mOsm} / \mathrm{kg}$ (Tiersch et al. 1997), in this study, $78 \%(n=27)$ of undiluted milt samples were below isotonicity and subject to premature activation. The apparent macrocephalus abnormality (Fig. 1) indicated cellular swelling and hypoosmotic stress, conditions that lessen chromatin integrity. In fact, a significantly higher number of cells with fragmented DNA was found in the low-osmolality buffer, which is

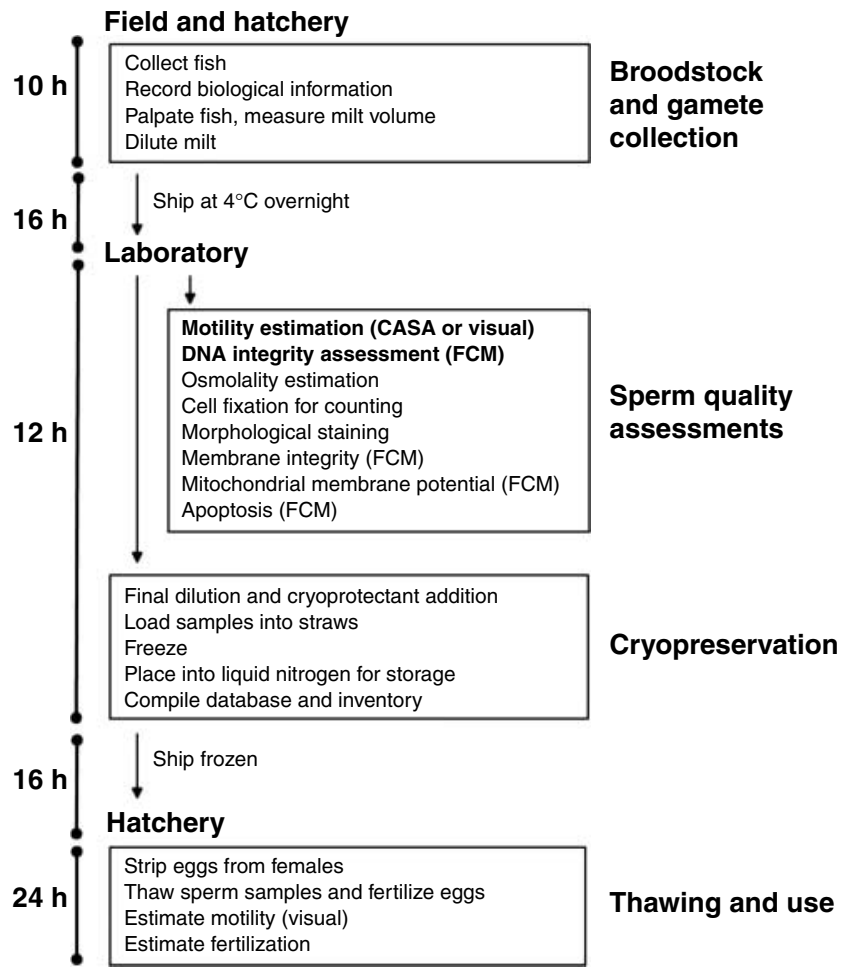

Figure 3 Overview and chronology of activities in the field, hatcheries, and laboratories for assessing sperm quality and cryopreservation of razorback sucker Xyrauchen texanus. The DNA integrity and motility estimations (bold) could be first in a tiered approach to assessing sperm quality.

less capable at counteracting the osmotic effects of urine than the high-osmolality buffer. In the short-term storage study, however, the visual estimates of razorback sucker sperm motilities were not dissimilar between the lowand high-osmolality buffers, but were different over time (Fig. 2). A follow-up study using objective CASA methods may provide useful data.

In a study of semen traits in natural wildlife populations of red deer Cervus elaphus hispanicus, sperm viability was proposed to not be directly associated with male fertility because viability is indispensable for fertilization, and males with low values have been intensively selected (Malo et al. 2005). However, membrane integrity assessments are integral for optimizing sperm handling and cryopreservation processes. Similar to an avian study (Blanco et al. 2000), attempts were made here to increase osmotic pressure by milt collection into higher osmolality $(500 \mathrm{mOsm} / \mathrm{kg})$ buffer, and this proved particularly useful for maintaining post-thaw viability. No differences were observed in prefreeze viability between the low- and high-osmolality buffers, yet significantly higher post-thaw values for viability and mitochondrial function were observed in the high-osmolality buffer (Table 1).

Sublethal cryopreservation damage to membranes is especially important for freshwater fish spermatozoa, whereby the ability to fertilize requires dilution 
in a hypoosmotic environment (Cabrita et al. 2001). Integrity of sperm plasma membranes is required for fertilization (Graham et al. 1990), yet cryopreservation reduced the percentage of membrane-intact spermatozoa (Cabrita et al. 2001) and impacted membrane structures in rainbow trout (Drokin et al. 1998). The lack of accord observed between fertilization rates and standard semen parameters or functional assessments (Linhart et al. 2005) may be partially explained by sublethal damage. In a study with sturgeon spermatozoa, various combinations of extenders and cryoprotectants yielding different osmolalities resulted in a variety of fertilization rates, even when post-thaw sperm motility and viability were similar to pre-freeze values (Horváth et al. 2008). The diverse biological properties of spermatozoa and dissimilarities among species underscore the use of a combination of sperm quality assessments, particularly in the less well-studied animals.

For CASA evaluations to be replicated, standardizations of instrument settings and protocols are needed for the species under study. Brief motilities of fish spermatozoa may be due to the relatively low mitochondrial number (Christen et al. 1987). In this study, spermatozoal movement occurred for $<30 \mathrm{~s}$ and was more linear than curvilinear. In mammals, linear movement has been attributed to mature spermatozoa (Syntin \& Robaire 2001) and to low intracellular calcium concentrations in European perch Perca fluviatilis (Alavi et al. 2007). Studies with non-threatened catostomid species may help in gaining insight into factors important to razorback sucker sperm motility (Syntin \& Robaire 2001), including aging, which is relevant in this long-lived species (e.g. 40 years; Minckley 1983).

Accuracy in estimating sperm number is important in ART (Evenson et al. 1993, Hansen et al. 2002), in the standardization of cryopreservation methods (Dong et al. 2007), for studies of environmental chemical impacts to reproductive health (Haubruge et al. 2000, Eustache et al. 2001), as well as in predicting fertility (Nadir et al. 1993) and post-thaw survival (Centola et al. 1992). No single counting method is uniformly preferred in andrology or research laboratories. Counting by FCM can lessen variability and decrease errors by discriminating debris and particulates from nuclei (Evenson et al. 1993, Eustache et al. 2001, Hansen et al. 2002), and it has been used with fish species (Jenkins \& Draugelis-Dale 2006). As in this study, positive linear relationships have been shown between spermatocrits and sperm density estimates (Tvedt et al. 2001). In this study, counts by FCM provided a complementary assay to DNA fragmentation and viability, being negatively correlated with increased levels of fragmentation and with post-thaw viability.

Investigations of DNA integrity are used in cancer biology, toxicology, environmental health studies (Potter et al. 2002), and in ART including IVF and ICSI (Donnelly et al. 2001). Proposed causes of DNA damage in human spermatozoa - defective sperm chromatin packaging, apoptosis, and oxidative stresses (Agarwal \& Said 2003) - can be extended to other species. Endogenous breaks may indicate anomalies during spermiogenesis and incomplete maturation (Manicardi et al. 1995). Rates of genomic DNA alterations or fragmentations ranged from $0.1 \%$ in ejaculates of fertile donors to $10 \%$ in infertile men (Ahmadi \& Ng 1999); another study showed that when $>30 \%$ of sperm DNA was damaged, natural pregnancy in mice was not possible (Evenson et al. 1999). In male mice Mus musculus, when the degree of DNA damage was $<8 \%$, oocyte-mediated mechanisms could repair it, yet, regardless of the degree of DNA damage, spermatozoa were capable of fertilization (Ahmadi \& Ng 1999). In ponds with higher concentrations of radionucleotides and genotoxicants, fecundity of western mosquitofish Gambusia affinis was negatively correlated with levels of double-stranded DNA breaks in spermatozoa as well as with the number of malformed embryos (Theodorakis et al. 1997).

Cryopreservation and osmotic stress can exacerbate DNA defects related to partially decondensed chromatin or DNA strand breakage (Peris et al. 2004, Silva \& Gadella 2006). Disparities in the levels of DNA damage between fertile and infertile men were shown following semen cryopreservation, where significantly more damage was observed in spermatozoa from the subfertile group (Hammadeh et al. 1999, Donnelly et al. 2001). DNA fragmentation assessments provided good correlation with bull fertility (Garcia-Macias et al. 2007). The structural integrity of DNA is particularly important for fish that employ external fertilization because of the osmotic challenge to spermatozoa.

Sperm chromatin of razorback suckers retains somaticlike histones for compaction, but not protamines or protamine-like sperm nuclear basic protein (SNBP) types (Frehlick 2009). The SNBPs decrease head volume, providing better protection against externally damaging agents. Identifying the SNBP types has implications for cryopreservation techniques, especially important for endangered species (Ausió et al. 2009). In this study, $20 \%$ of the razorback sucker milt samples before cryopreservation (pre-freeze) had nuclear DNA damage exceeding $10 \%$ of the population of nuclei. Because alterations in the primary structure of DNA in germ cells can result in heritable damage, such a FCM assay for DNA integrity with the endangered razorback suckers could be considered to be a quality control screening assay, as in a tiered testing approach to be performed before further assessments of sperm quality (Fig. 3). The NOMP method provides an additional means by which spermatozoal haplotypic DNA damage can be used in broodstock selection or for cryopreservation, and in examining betweenmale variation, as with a sperm chromatin dispersion assay used with tench Tinca tinca (López-Fernández et al. 2009). In fact, sperm chromatin has been considered an independent measure of sperm quality apart from standard sperm parameters (Agarwal \& Said 2003). 
Data on DNA integrity, supplementary to the typical sperm prognostic evaluators, can be informative in predictions of the response of spermatozoa to freezing (Hernández et al. 2006). Dietary ascorbic acid has been shown to maintain genetic integrity of spermatozoa by preventing oxidative damage to DNA in rainbow trout (Dabrowski \& Ciereszko 1996) and humans (Fraga et al. 1991), and its addition may be practical in extenders for razorback sucker milt. Generation of reactive oxygen species in human spermatozoa was shown to be related to DNA damage (Irvine et al. 2000). When performed following cryopreservation, the measure of chromatin condensation has been recommended as a sensitive parameter for sperm quality assessments (Hammadeh et al. 1999). In this study, discrepancies in the percentage of viability and mitochondrial membrane potential between the high- and low-osmolality buffers became apparent after thawing (Table 1). Similarly, differences were observed between pre- and post- thaw values of sperm motility and fertility with zebrafish Danio rerio (Yang et al. 2007).

Strategies for field collection and laboratory sperm quality assessments were developed for use with endangered razorback suckers, and the approach could be modified and adapted for use with other fish species. Collection of razorback sucker milt into a hypertonic buffer will enhance success in field collections of milt for meaningful analyses. The gamete quality assays developed for razorback suckers could be applied in selecting males for use in artificial spawning, for gamete cryopreservation, and for assessment of reproductive capacity in natural populations.

\section{Materials and Methods}

\section{Fish collection}

During the Lake Mohave annual spawning of razorback suckers in March, 2006, samples were collected by palpation from wild-caught individuals ( $n=64$ samples) and processed at Willow Beach National Fish Hatchery (WB), Willow Beach, Arizona, located 17 river km downstream from Hoover Dam. Fish were tagged with passive integrated transponders for identifying individuals (Biomark, Inc., Boise, ID, USA), weighed, and total lengths were measured. Milt samples were express-mailed at $5{ }^{\circ} \mathrm{C}$ for arrival at the Aquaculture Research Station (ARS), Louisiana State University Agricultural Center, Baton Rouge, Louisiana, USA. Sperm quality analyses were performed immediately upon receipt, during short-term cold storage for $33 \mathrm{~h}$, or following cryopreservation or fixation as described below.

\section{Collection and handling of spermatozoa}

Milt was allowed to flow freely for 1-2 s (Tiersch et al. 1997) before collection into sterile $50-\mathrm{ml}$ screw cap tubes. Because the activation of sperm motility in razorback suckers occurs at osmolalities below $270 \mathrm{mOsm} / \mathrm{kg}$, and the range of milt osmolalities at collection is typically wide due to contamination by urine (Tiersch et al. 1998), this study was designed to address such variability. Samples were collected into a 1:1 dilution with calcium-free Hanks' balanced salt solution (HBSS) at either 302 (just above isoosmotic conditions) or $500 \mathrm{mOsm} / \mathrm{kg}$ (hyperosmotic to account for potential dilution) at $\mathrm{pH}$ 7.4. Milt collected into different buffer treatments, as well as undiluted, was used in a short-term storage study of sperm motility at WB (see below). After centrifugation at $350 \mathrm{~g}$ for $10 \mathrm{~min}$, spermatocrits $(n=27)$ were obtained. Upon receipt at ARS, osmolalities were measured with a vapor pressure osmometer (Wescor Corp., Logan, UT, USA). Cells were frozen at $2 \times 10^{6} / \mathrm{ml}$ in a computer-controlled freezer with $0.5-\mathrm{ml}$ French straws (IMV International, Maple Grove, MN, USA) and 10\% dimethyl sulfoxide as a cryoprotectant, with 15 min equilibration, $-8^{\circ} \mathrm{C} / \mathrm{min}$ cooling rate, and thawing at $40^{\circ} \mathrm{C}$ for $10 \mathrm{~s}$. For cell counts and DNA integrity analyses by FCM, subsamples were fixed $1: 1$ by volume in 10\% buffered formalin, stored at $8{ }^{\circ} \mathrm{C}$, and analyzed 3 months later.

\section{Morphology of spermatozoa}

Sperm morphologies were assessed by diluting one part of the shipped sample to three parts HBSS, and one part of this suspension was mixed with seven parts of eosin-nigrosin (Lane Manufacturing, Inc., Denver, CO, USA) and smeared onto a slide by using the edge of a precleaned microscope slide. Preparations were air-dried and examined by using a light microscope (Leitz Diaplan, Wetzlar, Germany) at $1000 \times$ total magnification under oil immersion. Between 200 and 500 spermatozoa were evaluated per slide $(n=15)$ in accordance with the World Health Organization protocols (WHO 1987), whereby the two most commonly observed abnormalities (macrocephalic and cytoplasmic droplets) were scored in relation to apparent normal sperm morphologies.

\section{Motility of spermatozoa}

Spermatozoal motility was subjectively assessed visually, where one part of the shipped sample was diluted into two parts HBSS, and $0.25 \mu \mathrm{l}$ was diluted into $25 \mu \mathrm{l}$ deionized water $(18 \mathrm{mOsm} / \mathrm{kg})$ on a microscope slide to activate flagellar motion. The percentage of progressively motile cells was estimated using dark-field microscopy at $100 \times$ magnification. In a short-term cold storage study up to $33 \mathrm{~h}$, motility was recorded using undiluted milt and milt diluted $1: 1$ in saline or HBSS at low $(302 \mathrm{mOsm} / \mathrm{kg})$ and high osmolality $\left(500 \mathrm{mOsm} / \mathrm{kg}\right.$ ) held at $8{ }^{\circ} \mathrm{C}$. Motility values at each of the four time periods and for each of the five treatments were generated from the same ten individuals.

Motility was assessed with CASA by using a total of $25 \mu \mathrm{l}$ activated milt (as above; $n=13$ males) in a chambered slide (Leja 20 SC20-010040-B; Leja Products, Nieuw-Vennep, The Netherlands) and viewed with phase microscopy (Olympus BX41; Olympus America, Inc., Center Valley, PA, USA) at $200 \times$ magnification. Owing to the short-lived motility $(\sim 30 \mathrm{~s})$, one visual field per sample was electronically captured and analyzed (SpermVision, Version 3.0; Minitube of America, Verona, WI, USA). Software settings included area of cell identification $8 \times 30 \mu \mathrm{m}^{2}$; immotile at average 


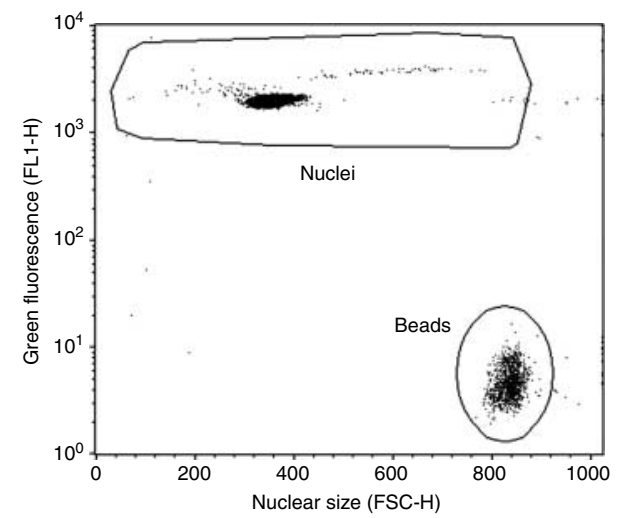

Figure 4 Flow cytometric dot plot illustrating the unknown concentration of razorback sucker sperm nuclei compared with a known number of fluorescent microbeads in one sample ( $n=32$ fish). Particle size is on the $x$-axis (forward scatter or FSC-H) and green fluorescence of stained nucleic acids and microspheres is on the $y$-axis (fluorescence detector FL1-H).

orientation of head $(\mu \mathrm{m} ; \mathrm{AOC})+$ distance straight line $(\mu \mathrm{m}$; DSL) $<25$ and DSL $<1$; local motile at DSL $<4$; hyperactive velocity curved line $(\mu \mathrm{m} / \mathrm{s} ; \mathrm{VCL})>80$ and linearity (LIN; as VSL/velocity average path) $<0.65$ and amplitude of lateral head displacement $(\mu \mathrm{m} ; \mathrm{ALH})>6.5$; linear straightness (STR; as VSL/VCL) $>0.7$ and LIN $>0.7$; non-linear STR $<0.9$ and $\mathrm{LIN}<0.5$; and curvilinear at DAP/radius $>3$ and $\mathrm{LIN}<0.5$. Total and progressive motilities, DSL, and distance curved line (DCL) parameters were statistically analyzed.

\section{Sperm counts}

Spermatozoa were manually counted $(n=9)$ with a Neubauer hemocytometer using the formula: count=sperm number in five small squares/ $80 \times\left(4.0 \times 10^{6}\right) \times$ (dilution factor). Spermatozoa were enumerated $(n=32)$ in duplicate with a commercial reagent (Bacteria Counting Kit, Molecular Probes, Eugene, OR, USA), whereby a fluorescent nucleic acid stain (SYTO BC) and a known concentration of fluorescent polystyrene microspheres were added to $10-\mu \mathrm{l}$ sample aliquots with $990 \mu \mathrm{l} \mathrm{HBSS}$ prior to analysis with a FACSCalibur (Becton Dickinson Immunocytometry Systems (BDIS), San Jose, CA, USA; Fig. 4).

\section{Sperm membrane integrity and mitochondrial membrane potential}

To validate flow cytometric assays for sperm membrane integrity and mitochondrial membrane potential, the shipped milt was used from each of three fish exhibiting $100 \%$ sperm motility by visual observations. Subsamples of $1 \times 10^{6}$ cell $\mathrm{s} / \mathrm{ml}$ in $3 \mathrm{ml} \mathrm{HBSS}$ heated at $70^{\circ} \mathrm{C}$ for $10 \mathrm{~min}$ and exhibiting no motility were considered non-viable and non-functional. Viable cells at the same concentration were combined with heat-treated cells in ratios of 100:0, 75:25, 50:50, 25:75, and $0: 100$. These live-dead cell combinations were used to generate regression lines between the expected viable (or functional) spermatozoa and the actual, measured values for membrane integrity and mitochondrial membrane potential.

Fluorescent stains used for membrane integrity were SYBR-14 and propidium iodide (PI; Live/Dead Sperm Viability kit, Molecular Probes), and rhodamine 123 (R123; Molecular Probes) and PI for mitochondrial membrane potential (Segovia et al. 2000, Silva \& Gadella 2006). After assay validation, the shipped samples were analyzed before (pre-freeze) and after (post-thaw) cryopreservation by FCM (see Table 1) as before, with an excitation wavelength of $488 \mathrm{~nm}$ following instrument calibration using FACSComp software (BDIS). Triplicate samples were analyzed, and 10000 cells per replicate were acquired and analyzed with CellQuest software (BDIS).

\section{DNA integrity}

To validate DNA integrity analyses, the shipped milt was used from razorback suckers and from common carp Cyprinus carpio induced by pituitary extract injection (Rottmann et al. 1991). Razorback sucker spermatozoa were diluted to $4 \times 10^{6}$ cell $/ \mathrm{ml}$ and subjected for $4 \mathrm{~h}$ to freshly opened hydrogen peroxide
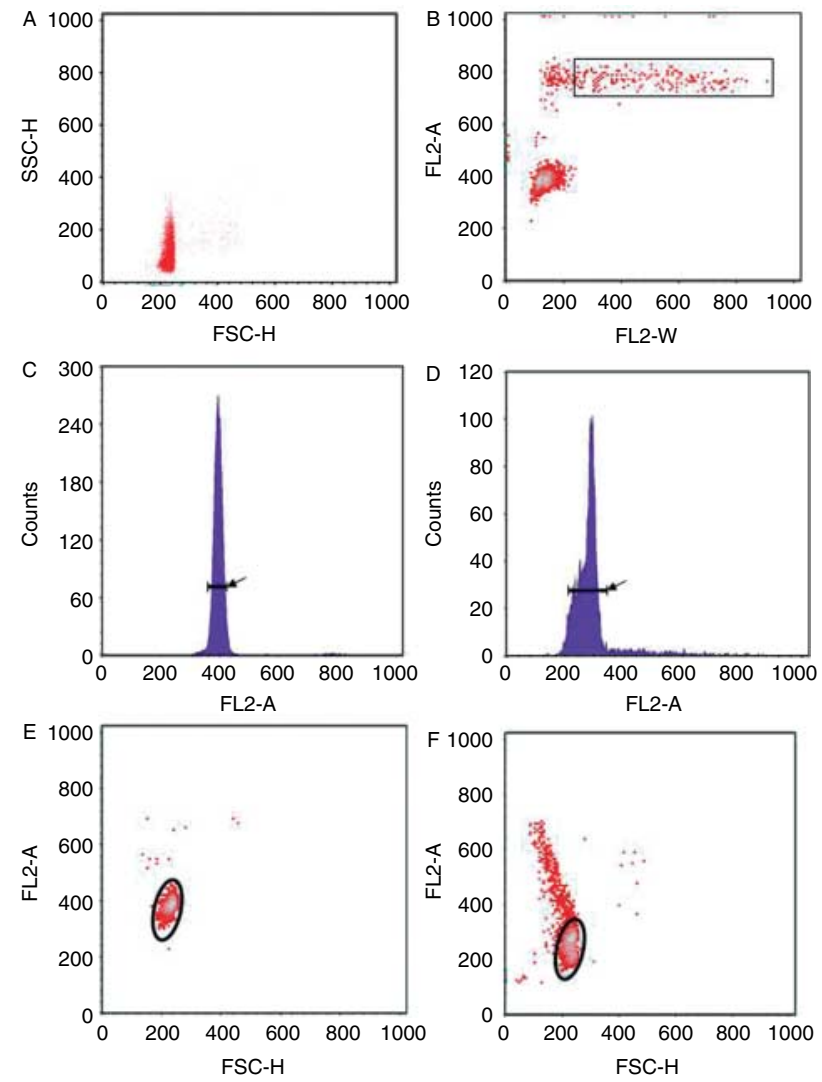

Figure 5 Flow cytometric plots showing nuclei of razorback sucker spermatozoa stained with propidium iodide. (A) The main population of nuclei is shown with size (FSC-H) on the $x$-axis and scatter (SSC-H) on the $y$-axis. (B) Nuclear aggregates are removed (rectangular gate) from further analysis by using doublet discrimination mode with width (FL2-W) and area (FL2-A). (C) A histogram of razorback sucker \#3 showing the primary spermatozoal haploid peak with coefficient of variation $(\mathrm{CV})=3.15$ (arrow), and (D), the CV (arrow) from razorback sucker $\# 15$ is 10.01 , showing a wider dispersion of nuclear fluorescence. (E) The percentage of nuclei from razorback sucker $\# 3$ outside the main population (outside the gated circle; NOMP) is equal to $0.3 \%$, and (F) with razorback sucker $\# 15$, NOMP is $10.5 \%$, showing fragmented DNA primarily having higher fluorescence (FL2-A) and smaller size (FSC-H) than the main population of nuclei (circle gate). 
(Sigma-Aldrich; $150 \mathrm{mM}$ in HBSS) dilutions (0-100\% at 10\% intervals) to damage DNA (Donnelly 1999, Termini 2000, Potter et al. 2002). Carp milt was similarly diluted and exposed to $0,75,85,95$, and $100 \%$ hydrogen peroxide and analyzed immediately and after subsample fixation with $2 \%$ paraformaldehyde.

The shipped fixed razorback sucker milt $(n=32)$ was diluted to $2 \times 10^{6}$ cells $/ \mathrm{ml}$ and stained with PI $(25 \mu \mathrm{g} / \mathrm{ml})$, DNase-free RNase $A$ at $1 \mu \mathrm{g} / \mathrm{ml}$, and $0.1 \%(\mathrm{v} / \mathrm{v})$ Triton X-100 in sodium citrate (Sigma-Aldrich) for $30 \mathrm{~min}$ at $24{ }^{\circ} \mathrm{C}$ in the darkness (Crissman \& Steinkamp 1973). Stained nuclei were filtered through 30- $\mu$ m nylon mesh (Small Parts, Miami Lakes, FL, USA) prior to analysis in duplicate by FCM. Nuclei were analyzed at $1 \times 10^{6} / \mathrm{ml}$ at a rate of fewer than 300 per s, and 10000 events per sample in duplicate were collected by using a 1024-channel FL2 parameter measured at $585 \mathrm{~nm}$. Cytograms were generated using CellQuest (BDIS) upon linear analysis of nuclei in forward scatter (FSC-H) (size) versus side scatter (SSC; Fig. 5A). Aggregates were gated out from analysis using doublet discrimination mode with FL2 width (FL2W) versus FL2 area (FL2A; Fig. 5B). CV were measured from the main histogram (haploid) peak (Fig. 5C and D) and nuclei with fluorescence outside the main population (NOMP) were denoted in dot plots generated by FSC versus FL2A (Fig. 5E and F), where larger values for each $C V$ and NOMP were indicative of higher levels of DNA fragmentation.

\section{Statistical analysis}

Assay results were not generated for each shipped sample of razorback sucker milt because of limited fish numbers, constraints in field collections, shipping, and instrument performance. Differences were tested among sperm quality parameters from milt collected in 302 or $500 \mathrm{mOsm} / \mathrm{kg}$ HBSS. Arcsine (sqrt) transformations were applied to proportions (percentage) data, and cell counts were log transformed. Unequal variances in morphology and DNA fragmentation data necessitated the use of two parametric $t$-tests, whereas oneway ANOVA was performed with other data. A two-way ANOVA was performed for the analysis of motility during cold storage. Correlations between sperm quality results were examined. Models for the best fit regression of hydrogen peroxide-exposed spermatozoa with fresh carp and razorback sucker sperm and fixed carp sperm were generated for NOMP and CV. Differences in DNA fragmentation among fish were tested by ANOVA. The level of significance was $\alpha=0.05$, and all statistical analyses were performed using SAS (SAS Institute 1999).

\section{Declaration of interest}

The authors declare that there is no conflict of interest that could be perceived as prejudicing the impartiality of the research reported.

\section{Funding}

Supported in part by funding from the Louisiana Sea Grant College Program.

\section{Acknowledgements}

We thank A D Perez for morphological data, A Parrish for formatting of the manuscript, and $\mathrm{R}$ Staton for production of microscopic images. The authors thank C Marr, G Knowles, L Fitzpatrick, $H$ Olivier, and S Goodbred for reviewing the manuscript. This manuscript has been accepted by the Director of the Louisiana Agricultural Experiment Station as number 2009-244-3901. Any use of trade, product, or firm names is for descriptive purposes only and does not imply endorsement by the US Government or the LSU Agricultural Center.

\section{References}

Aas GH, Refstie T \& Gjerde B 1991 Evaluation of milt quality of Atlantic salmon. Aquaculture 95 125-132. (doi:10.1016/0044-8486(91)90079-M) Agarwal A \& Said TM 2003 Role of sperm chromatin abnormalities and DNA damage in male infertility. Human Reproduction Update 9 331-345. (doi:10.1093/humupd/dmg027)

Ahmadi A \& Ng S-C 1999 Fertilizing ability of DNA-damaged spermatozoa. Journal of Experimental Zoology 284 696-704. (doi:10.1002/(SICl) 1097-010X(19991101)284:6<696::AID-JEZ11 > 3.0.CO;2-E)

Alanen KA, Joensuu H \& Klemi PJ 1989 Autolysis is a potential source of false aneuploid peaks in flow cytometric DNA histograms. Cytometry 10 417-425. (doi:10.1002/cyto.990100409)

Alavi SMH, Rodina M, Policar T, Kozak P, Psenicka M \& Linhart O 2007 Semen of Perca fluviatilis L.: sperm volume and density, seminal plasma indices and effects of dilution ratio, ions and osmolality on sperm motility. Theriogenology 68 276-283. (doi:10.1016/j.theriogenology. 2007.05.045)

Ausió J, Eirín-Lopez JM \& Frehlick LJ 2009 Evolution of vertebrate chromosomal sperm proteins: implications for fertility and sperm competition. In Spermatology, pp 63-79. Eds ERS Roldan \& M Gomendio. Nottingham, UK: Nottingham University Press.

Bainbridge DRJ \& Jabbour HN 1998 Potential of assisted breeding techniques for the conservation of endangered mammalian species in captivity: a review. Veterinary Record 143 159-168. (doi:10.1136/ vr.143.6.159)

Barnett TP \& Pierce DW 2008 When will Lake Mead go dry? Water Resources Research 44 W03201. (doi:10.1029/2007WR006704)

Bawa KS, Menon S \& Gorman LR 1997 Cloning and conservation of biological diversity: paradox, panacea, or Pandora's box? Conservation Biology 11 829-830. (doi:10.1046/j.1523-1739.1997.011004829.x)

Bickham JW, Sawin VL, Burton DW \& McBee K 1992 Flow cytometry analysis of the effects of triethylenemelamine on somatic and testicular tissue of the rat. Cytometry 13 368-373. (doi:10.1002/cyto. 990130406)

Blanco JM, Gee G, Wildt DE \& Donoghue AM 2000 Species variation in osmotic, cryoprotectant, and cooling rate tolerance in poultry, eagle, and peregrine falcon spermatozoa. Biology of Reproduction 63 1164-1171. (doi:10.1095/biolreprod63.4.1164)

Cabrita E, Martinez F, Real M, Alvarez R \& Herraez MP 2001 The use of flow cytometry to assess membrane stability in fresh and cryopreserved trout spermatozoa. Cryo Letters 22 263-272.

Carmichael GJ, Williamson JH, Gorman OT \& Tiersch TR 1996 Field propagation techniques for the endangered razorback sucker. North American Journal of Fisheries Management 16 963-966. (doi:10.1577/ 1548-8675(1996)016<0963:FPTFTE > 2.3.CO;2)

Centola GM, Raubertas RF \& Mattox JH 1992 Cryopreservation of human semen. Comparison of cryopreservatives, sources of variability, and prediction of post-thaw survival. Journal of Andrology 13 283-288.

Christen R, Gatti JL \& Billard R 1987 Trout sperm motility. The transient movement of trout sperm is related to changes in the concentration of ATP following the activation of the flagellar movement. European Journal of Biochemistry 166 667-671. (doi:10.1111/j.1432-1033.1987. tb13565.x)

Comizzoli P, Mermillod P \& Mauget R 2000 Reproductive biotechnologies from endangered mammalian species. Reproduction, Nutrition, Development 40 493-504. (doi:10.1051/rnd:2000113) 
Cooke SJ, Bunt CM, Hamilton SJ, Jennings CA, Pearson MP, Cooperman MS \& Markle DF 2005 Threats, conservation strategies, and prognosis for suckers (Catostomidae) in North America: insights from regional case studies of a diverse family of non-game fishes. Biological Conservation 121 317-331. (doi:10.1016/j.biocon.2004.05.015)

Crissman HA \& Steinkamp JA 1973 Rapid simultaneous measurement of DNA, protein and cell volume in single cells from large mammalian cell populations. Journal of Cell Biology 59 766-771. (doi:10.1083/jcb.59.3.766)

Dabrowski K \& Ciereszko A 1996 Ascorbic acid protects against male infertility in a teleost fish. Cellular and Molecular Life Sciences $\mathbf{5 2}$ 97-100. (doi:10.1007/BF01923351)

Dallas CE \& Evans DL 1990 Flow cytometry in toxicity analysis. Nature 345 557-558. (doi:10.1038/345557a0)

Dong Q, Huang C \& Tiersch TR 2007 Control of sperm concentration is necessary for standardization of sperm cryopreservation in aquatic species: evidence from sperm agglutination in oysters. Cryobiology $\mathbf{5 4}$ 87-98. (doi:10.1016/j.cryobiol.2006.11.007)

Donnelly ET, McClure N \& Lewis SEM 1999 The effect of ascorbate and $\alpha$-tocopherol supplementation in vitro on DNA integrity and hydrogen peroxide-induced DNA damage in human spermatozoa. Mutagenesis $\mathbf{1 4}$ 505-512. (doi:10.1093/mutage/14.5.505)

Donnelly ET, Steele EK, McClure N \& Lewis SEM 2001 Assessment of DNA integrity and morphology of ejaculated spermatozoa from fertile and infertile men before and after cryopreservation. Human Reproduction 16 1191-1199. (doi:10.1093/humrep/16.6.1191)

Drokin S, Stein H \& Bartscherer H 1998 Effect of cryopreservation on the fine structure of spermatozoa of rainbow trout (Oncorhynchus mykiss) and brown trout (Salmo trutta F. fario). Reproduction, Fertility, and Development 37 263-270. (doi:10.1006/cryo.1998.2123)

Ericsson SA, Garner DL, Thomas CA, Downing TW \& Marshall CE 1993 Interrelationships among fluorometric analyses of spermatozoal function, classical semen quality parameters and the fertility of frozenthawed bovine spermatozoa. Theriogenology 39 1009-1024. (doi:10. 1016/0093-691X(93)90002-M)

Eustache R, Jouannet P \& Auger J 2001 Evaluation of flow cytometric methods to measure human sperm concentration. Journal of Andrology 22 558-567.

Evenson DP, Parks JE, Kaproth MT \& Jost LK 1993 Rapid determination on sperm cell concentration in bovine semen by flow cytometry. Journal of Dairy Science 76 86-94. (doi:10.3168/jds.S0022-0302(93)77326-9)

Evenson DP, Jost LK, Marshall D, Zinaman MJ, Clegg E, Puvis K, De Angelis P \& Claussen OP 1999 Utility of sperm chromatin structure assay as a diagnostic and prognostic tool in the human fertility clinic. Human Reproduction 14 1039-1049. (doi:10.1093/humrep/14.4.1039)

Evenson DP, Kasperson K \& Wixon RL 2007 Analysis of sperm DNA fragmentation using flow cytometry and other techniques. In Spermatology, pp 93-113. Eds ERS Roldan \& M Gomendio. Nottingham, UK: Nottingham University Press.

Fraga CG, Motchnik PA, Shigenaga MK, Helbock HJ, Jacob RA \& Ames BN 1991 Ascorbic acid protects against endogenous oxidative DNA damage in human sperm. PNAS 88 11003-11006. (doi:10.1073/pnas.88.24.11003)

Frehlick LJ 2009 Chromatin remodelling in vertebrate spermatozoa. PhD Thesis, p 156. University of Victoria, British Columbia, Canada. http:// dspace.library.uvic.ca:8080/handle/1828/2024.

Garcia-Macias V, de Paz P, Martinez-Pastor F, Alvarez M, Gomes-Alves S, Bernardo J, Anel E \& Anel L 2007 DNA fragmentation assessment by flow cytometry and Sperm-Bos-Halomax (bright-field microscopy and fluorescence microscopy) in bull sperm. International Journal of Andrology 30 88-98. (doi:10.1111/j.1365-2605.2006.00723.x)

Goodbred S, Leiker TJ, Patino R, Jenkins JA, Denslow ND, Orsak E \& Rosen MR 2007 Organic chemical concentrations and reproductive biomarkers in common carp (Cyprinus carpio) collected from two areas in Lake Mead, Nevada, May 1999-May 2000. US Geological Survey Data Series 286, p 18, 1-18.

Graham JK, Kunze E \& Hammerstedt RH 1990 Analysis of sperm cell viability, acrosomal integrity, and mitochondrial function using flow cytometry. Biology of Reproduction 43 55-64. (doi:10.1095/biolreprod43.1.55)

Gwo J-C, Ohta H, Okuzawa K \& Wu H-C 1999 Cryopreservation of sperm from the endangered Formosan landlocked salmon (Oncorhynchus masou formosanus). Theriogenology 51 569-582. (doi:10.1016/S0093691X(99)00011-4)
Hammadeh ME, Askari AS, Georg T, Rosenbaum P \& Schmidt W 1999 Effect of freeze-thawing procedure on chromatin stability, morphological alteration and membrane integrity of human spermatozoa in fertile and subfertile men. International Journal of Andrology 22 155-162. (doi:10. 1046/j.1365-2605.1999.00162.x)

Hansen C, Christensen P, Stryhn H, Hedeboe AM, Rode M \& Boe-Hansen G 2002 Validation of the FACSCount AF system for determination of sperm concentration in boar semen. Reproduction in Domestic Animals 37 330-334. (doi:10.1046/j.1439-0531.2002.00367.x)

Haubruge E, Petit F \& Gage MJG 2000 Reduced sperm counts in guppies (Poecilia reticulata) following exposure to low levels of tributylin and bisphenol A. Proceedings of the Royal Society of London. Series B $\mathbf{2 6 7}$ 2333-2337. (doi:10.1098/rspb.2000.1288)

Hernández M, Roca J, Ballester J, Vázquez JM, Martinez EA, Johannisson A, Saravia F \& Rodriguez-Martinez H 2006 Differences in SCSA outcome among boars with different sperm freezability. International Journal of Andrology 29 583-591. (doi:10.1111/j.13652605.2006.00699.x)

Horváth Á, Wayman WR, Dean JC, Urbányi B, Tiersch TR, Mims SD, Johnson D \& Jenkins JA 2008 Viability and fertilizing capacity of cryopreserved sperm from three North American acipenseriform species: a retrospective study. Journal of Applied Ichthyology 24 443-449. (doi:10.1111/j.1439-0426.2008.01134.x)

Irvine DS, Twigg JP, Gordon EL, Fulton N, Milne PA \& Aitken RJ 2000 DNA integrity in human spermatozoa: relationships with semen quality. Journal of Andrology 21 33-44.

Jenkins JA 2000 Infectious disease and quality assurance considerations for the transfer of cryopreserved fish gametes. In Cryopreservation in Aquatic Species, pp 343-363. Eds TR Tiersch \& PM Mazik. Baton Rouge, LA: World Aquaculture Society.

Jenkins JA \& Draugelis-Dale R 2006 Bioindicators from mosquitofish (Gambusia affinis) sampled from the Imperial Valley in Southern California. OFR, OF 2006-1307, p 48, 1-48.

Jenkins JA \& Goodbred SL 2005 Viability of male gametes in common carp (Cyprinus carpio) along the Lower Colorado River from the Cibola National Wildlife Refuge (NWR), Havasu NWR, and Lake Mohave of Lake Mead National Recreation Area. OFR, OF 2006-1007, p 25, 1-25.

Johnson LV, Walsh ML \& Chen LB 1980 Localization of mitochondria in living cells with rhodamine 123. PNAS 77 990-994. (doi:10.1073/pnas. 77.2.990)

Labbe C, Martoriati A, Devaux A \& Maisse G 2001 Effect of sperm cryopreservation on sperm DNA stability and progeny development in rainbow trout. Molecular Reproduction and Development 60 397-404. (doi:10.1002/mrd.1102)

Linhart O, Rodina M, Flajshans M, Gela D \& Kocour M 2005 Cryopreservation of European catfish Silurus glanis sperm: sperm motility, viability, and hatching success of embryos. Cryobiology $\mathbf{5 1}$ 250-261. (doi:10.1016/j.cryobiol.2005.07.005)

López-Fernández C, Gage MJG, Arroyo F, Gosálbez A, Larrán AM, Fernández JL \& Gosálvez J 2009 Rapid rates of sperm DNA damage after activation in tench (Tinca tinca: Teleostei, Cyprinidae) measured using a sperm chromatin dispersion test. Reproduction 138 257-266. (doi:10. 1530/REP-09-0105)

Malo AF, Garde JJ, Soler AJ, Garcia AJ, Gomendio M \& Roldan ERS 2005 Male fertility in natural populations of red deer is determined by sperm velocity and the proportion of normal spermatozoa. Biology of Reproduction 72 822-829. (doi:10.1095/biolreprod.104. 036368)

Manicardi G, Bianchi P, Pantano S, Azzoni P, Bizzaro D, Bianchi U \& Sakkas D 1995 Presence of endogenous nicks in DNA of ejaculated human spermatozoa and its relationship to chromomycin $A_{3}$ accessibility. Biology of Reproduction 52 864-867. (doi:10.1095/biolreprod52.4.864)

Marchetti C, Obert G, Deffosez A, Formstecher P \& Marchetti P 2002 Study of mitochondrial membrane potential, reactive oxygen species, DNA fragmentation and cell viability by flow cytometry in human sperm. Human Reproduction 17 1257-1265. (doi:10.1093/ humrep/17.5.1257)

Minckley WL 1983 Status of the razorback sucker, Xyrauchen texanus (Abbott), in the lower Colorado basin. Southwestern Naturalist 28 165-187. (doi:10.2307/3671385) 
Minckley WL, Marsh PC, Brooks JE, Johnson JE \& Jensen BL 1991 Management toward recovery of the razorback sucker. In Battle Against Extinction: Native Fish Management in the American West, pp 303-357. Eds WL Minckley \& JE Deacon. Tuscon, AZ: University of Arizona Press.

Modde T, Burnham KP \& Wick EJ 1996 Population status of the razorback sucker in the middle Green River (USA). Conservation Biology 10 110-119. (doi:10.1046/j.1523-1739.1996.10010110.x)

Mueller G, Marsh PC, Knowles G \& Wolters T 2000 Distribution, movements, and habitat use of razorback sucker (Xyrauchen texanus) in a lower Colorado River reservoir, Arizona-Nevada. Western North American Naturalist 60 180-187.

Nadir S, Saacke RG, Bame J, Mullins J \& Degelos S 1993 Effect of freezing semen and dosage of sperm on number of accessory sperm, fertility, and embryo quality in artificially inseminated cattle. Journal of Animal Science 71 199-204.

Ohta H, Kawamura K, Unuma T \& Takegoshi Y 2001 Cryopreservation of the sperm of the Japanese bitterling. Journal of Fish Biology 58 670-681. (doi:10.1111/j.1095-8649.2001.tb00521.x)

Paniagua-Chavez CG, Jenkins J, Segovia M \& Tiersch TR 2006 Assessment of gamete quality for the eastern oyster (Crassostrea virginica) by use of fluorescent dyes. Cryobiology 53 128-138. (doi:10.1016/j.cryobiol. 2006.05.001)

Peris SI, Morrier A, Dufour M \& Bailey JL 2004 Cryopreservation of ram semen facilitates sperm DNA damage: relationship between sperm andrological parameters and the sperm chromatin structure assay. Journal of Andrology 25 224-233.

Potter AJ, Gollahon KA, Palanca BJA, Harbert MJ, Choi YM, Moskovitz AH, Potter JD \& Rabinovitch PS 2002 Flow cytometric analysis of the cell cycle phase specificity of DNA damage induced by radiation, hydrogen peroxide and doxorubicin. Carcinogenesis 23 389-401. (doi:10.1093/ carcin/23.3.389)

Rottmann RW, Shireman JV \& Chapman FA 1991 Hormone preparation, dosage calculation, and injection techniques for induced spawning of fish. Southern Regional Aquaculture Center 425, p 4. https://srac.tamu. edu/index.cfm/event/getFactSheet/whichfactsheet/88/.

Rurangwa E, Kime DE, Ollevier F \& Nash JP 2004 The measurement of sperm motility and factors affecting sperm quality in cultured fish. Aquaculture 234 1-28. (doi:10.1016/j.aquaculture.2003.12.006)

Sailer BL, Jost LK \& Evenson DP 1995 Mammalian sperm DNA susceptibility to in situ denaturation associated with the presence of DNA strand breaks as measured by the terminal deoxynucleotidyl transferase assay. Journal of Andrology 16 80-87.

SAS Institute 1999 SAS/STAT User's Guide, Version 8. Cary, NC: SAS Institute Inc.

Segovia M, Jenkins JA, Paniagua-Chavez C \& Tiersch TR 2000 Flow cytometric evaluation of antibiotic effects on viability and mitochondrial function of refrigerated sperm of Nile tilapia. Theriogenology $\mathbf{5 3}$ 1489-1499. (doi:10.1016/S0093-691X(00)00291-0)

Shapiro HM 1995 Practical Flow Cytometry, New York: Wiley-Liss.

Silva PFN \& Gadella BM 2006 Detection of damage in mammalian sperm cells. Theriogenology 65 958-978. (doi:10.1016/j.theriogenology.2005. 09.010)

Singh NP, Danner DB, Tice RR, McCoy MT, Collins GD \& Schneider EL 1989 Abundant alkali-sensitive sites in DNA of human and mouse sperm. Experimental Cell Research 184 461-470. (doi:10.1016/00144827(89)90344-3)

Soler AJ, Esteso MC, Fernandez-Santos MR \& Garde JJ 2005 Characteristics of Iberian red deer (Cervus elaphus hispanicus) spermatozoa cryopreserved after storage at $5{ }^{\circ} \mathrm{C}$ in the epididymis for several days. Theriogenology 64 1503-1517. (doi:10.1016/j.theriogenology.2005.03. 013)

Spanò M, Bonde JP, Hiøllund HI, Kolstad HA, Cordelli E \& Leter G 2000 Sperm chromatin damage impairs human fertility. Fertility and Sterility 73 43-50. (doi:10.1016/S0015-0282(99)00462-8)

Suquet M, Dreanno C, Fauvel C, Cosson J \& Billard R 2000 Cryopreservation of sperm in marine fish. Aquaculture Research 31 231-243. (doi:10. 1046/j.1365-2109.2000.00445.x)

Syntin P \& Robaire B 2001 Sperm structural and motility changes during aging in the brown Norway rat. Journal of Andrology 22 235-244.

Termini J 2000 Hydroperoxide-induced DNA damage and mutations. Mutation Research 450 107-124. (doi:10.1016/S0027-5107(00)00019-1)
Terner C 1986 Evaluation of salmonid sperm motility for cryopreservation. The Progressive Fish-Culturist 48 230-232. (doi:10.1577/1548-8640 (1986) $48<230$ :EOSSMF $>2.0$. CO;2)

Theodorakis CW, Blaylock BG \& Shugart LR 1997 Genetic ecotoxicology. 1. DNA integrity and reproduction in mosquitofish exposed in situ to radionuclides. Ecotoxicology 6 205-218. (doi:10.1023/A:101867 4727022)

Tice RR, Agurell E, Anderson D, Burlinson B, Hartmann A, Kobayashi H, Miyamae Y, Rojas E, Ryu J-C \& Sasaki YF 2000 Single cell gel/comet assay: guidelines for in vitro and in vivo genetic toxicology testing. Environmental and Molecular Mutagenesis 35 206-221. (doi:10.1002/ (SICl)1098-2280(2000)35:3 <206::AID-EM8 > 3.0.CO;2-J)

Tiersch TR, Wayman WR, Figiel CR, Gorman OT, Williamson JH \& Carmichael GJ 1997 Field collection, handling, and storage of sperm of the endangered razorback sucker. North American Journal of Fisheries Management 17 167-173. (doi:10.1577/1548-8675(1997) $017<0167$ :FCHASO > 2.3.CO;2)

Tiersch TR, Figiel CR, Wayman WR, Williamson JH, Carmichael GJ \& Gorman OT 1998 Cryopreservation of sperm of the endangered razorback sucker. Transactions of the American Fisheries Society 127 95-104. (doi:10.1577/1548-8659(1998)127<0095:COSOTE $>2$. $0 . \mathrm{CO} ; 2)$

Tiersch TR, Wayman WR, Skapura DP \& Grier HJ 2004 Transport and cryopreservation of sperm of the common snook, Centropomus undecimalis (Bloch). Aquaculture Research 35 278-288. (doi:10.1111/ j.1365-2109.2004.01013.x)

Tiersch TR, Yang H, Jenkins JA \& Dong Q 2007 Sperm cryopreservation in fish and shellfish. In Spermatology, pp 493-508. Eds ERS Roldan \& M Gomendio. Nottingham, UK: Nottingham University Press.

Tvedt HB, Benfey TJ, Martin-Robichaud DJ \& Power J 2001 The relationship between sperm density, spermatocrit, sperm motility and fertilization success in Atlantic halibut, Hippoglossus hippoglossus. Aquaculture 194 191-200. (doi:10.1016/S0044-8486(00)00516-0)

US Fish \& Wildlife Service 1991 Endangered and Threatened Wildlife and Plants: the Razorback Sucker (Xyrauchen texanus) Determined to be an Endangered Species, Final Rule. Federal Register 56 (23 October 1991): 54957-54967.

US Fish \& Wildlife Service 2002 Razorback sucker (Xyrauchen texanus) Recovery Goals: Amendment and Supplement to the Razorback Sucker Recovery Plan. 1-113. Denver, Colorado, Mountain-Prairie Region (6).

Verstegen J, Iguer-Ouada M \& Onclin K 2002 Computer assisted semen analyzers in andrology research and veterinary practice. Theriogenology 57 149-179. (doi:10.1016/S0093-691X(01)00664-1)

Waddell B \& May T 1995 Selenium concentrations in the razorback sucker (Xyrauchen texanus): substitution of non-lethal muscle plugs for muscle tissue in contaminant assessment. Archives of Environmental Contamination and Toxicology 28 321-326. (doi:10.1007/BF00213109)

Wayman WR 2003 From gamete collection to database development: development of a model cryopreserved germplasm repository for aquatic species with emphasis on sturgeon. PhD Thesis, p 195. Louisiana State University, USA. http://etd.lsu.edu/docs/available/etd-0710103-135135/.

World Health Organization 1987 Laboratory Manual for the Examination of Human Semen and Semen-Cervical Mucus Interaction, Cambridge, UK: Cambridge University Press.

Yang H, Carmichael C, Varga ZM \& Tiersch TR 2007 Development of a simplified and standardized protocol with potential for high-throughput for sperm cryopreservation in zebrafish Danio rerio. Theriogenology 68 128-136. (doi:10.1016/j.theriogenology.2007.02.015)

Zbieranowski I, Demianink C, Bell V, Knape WA \& Murray D 1993 Detection of false DNA aneuploidy and false DNA multiploidy in flow cytometric DNA analysis. Analytical Cellular Pathology 5 69-84.

Zilli L, Schiavone R, Zonno V, Storelli C \& Vilella S 2003 Evaluation of DNA damage in Dicentrarchus labrax sperm following cryopreservation. Cryobiology 47 227-235. (doi:10.1016/j.cryobiol.2003.10.002)

Received 23 March 2010

First decision 19 May 2010

Revised manuscript received 2 September 2010

Accepted 18 October 2010 